\title{
Evaluating faith after conversion
}

\section{Arguments in religious media on the place of religious expertise in asylum appeals in Finland}

l: 2017, the Finnish Immigration Service received approximately 1,000 asylum applications and appeals based on conversion from Islam to Christianity. The applications claimed that converted asylum seekers would face mortal danger if returned to their countries of origin. The applications posed an unprecedented dilemma for the Finnish Immigration Service: how was it, as a secular state institution, to evaluate these claims of conversion? This question also became an object of significant public and media debate. In this article, I examine how journalists writing for a religious media publication, Kirkko ja kaupunki, the newspaper of the Evangelical Lutheran Church in the Helsinki region, sought to intervene in the debate on asylum seekers' conversions. I focus my analysis on one central line of argument in their reporting: a call for the better inclusion of and engagement with religious expertise on Christianity by the Finnish Immigration Service when evaluating conversion-based asylum applications and appeals. I show that this call both positioned religious expertise as an antidote to the challenges that efforts to evaluate conversion-based asylum appeals posed to Finnish Immigration Service employees in this time period, and constituted expertise as a site for negotiations over the 'proper' relationship between religion and state.

'STRANGE THINGS ARE HAPPENING in wild small congregations as asylum seekers are converting en masse to Christianity' reported Helsingin Sanomat on 4 March
2018 (Huhtanen 2018). ${ }^{1}$ According to the article's subhead, over 1,00o asylum seekers, predominantly from Iraq and Afghanistan, had applied for asylum based on conversion to Christianity in Finland in 2017. This newspaper article was one of a large number of media reports and analyses on the rise in such asylum applications. The tone of these reports varied greatly. Some like this one were alarmist, drawing attention to the purportedly strategic and 'wild' character of asylum seekers' conversions. Others were more sympathetic, arguing that even if conversion had originally been strategically motivated, most converted asylum seekers had come to find a new faith in Christianity in the process and as such faced persecution if they were returned to their home countries. These latter kinds of analysis were especially prevalent in religious media publications such as Kirkko ja kaupunki, the biweekly newspaper of the Evangelical Lutheran

1 Helsingin Sanomat, published in Helsinki, is Finland's largest circulating daily newspaper. Its circulation in 2018 was 332,717 . According to the Finnish National Media research centre, it was read on average by $1,716,000$ people daily (almost $1 / 3$ of the nation's population (MediaAudit Finland 2019). 
Church in the Helsinki region, that tended to view the conversion of asylum seekers to Christianity as a welcome development and argue for viewing conversion as a multifaceted and gradual process.

Irrespective of the news reports' tone or attitudes towards asylum seekers' conversion-based appeals, however, they were centrally concerned with one question; that of how the sincerity of faith and conversion could and should be evaluated. Was the conversion of individual asylum seekers 'real' or was it 'strategic'? How was the truthfulness of conversion in these cases to be analysed? Who could or should make that determination and how? By what criteria, and crucially on the basis of what kind of, and whose, expertise? To what extent could assessments of faith and conversion even be made by secular state officials, and how should they go about evaluating these asylum appeals?

The stakes of these questions were high. Not only did they highlight the challenges that asylum seekers' conversions to Christianity posed for Finnish immigration authorities, but also they drove to the core of a central problem of secular governance: how should secular governments and government institutions engage with legal arguments based on religion? Conventionally, secularism has been understood in terms of a separation between religion and state. But, as recent scholarship has variously demonstrated, secularism is better understood as a form of governance that is centrally concerned with the management of religion (see esp. Asad 2003; see also Agrama 2010; Bowen 2007; Fernando 2014; Sullivan 2005). That is, rather than an effort to purge religion from the public and political spheres, secularism consists of the government regulation of the place of religion in these spheres - the degree to which religious elements can be present in public spaces, the manner in which religious groups are constrained or supported by government institutions, and crucially, the ways in which religious views are heard in political debates and governance. ${ }^{2}$ As Hussein Ali Agrama, an anthropologist of secularism and law, has evocatively argued in an analysis of Egyptian secularism, efforts to draw a line between religion and secular governance are never complete, but rather always on-going. There are no easy or clear-cut answers to what the 'proper' relationship of religion and politics in secular polities is. Instead, secularism is, by its very nature, constitutive of, and constituted by, what Agrama (2010) calls a 'historical problem-space', a discursive space that is formed through, and oriented towards, determining the proper relationship between religion and politics.

The debates that are produced by and constitutive of this problem-space tend to be heated and contentious. The stakes are high and the parties involved are all variously invested. This raises the question of the terms by which the debates unfold. What are the conditions of possibility for argument in general, and what are they in particular for arguments that can shift where the lines between religion and politics are drawn? In this article, I examine the ways in which, and the extent to which, a frame of expertise provided religious actors with a basis for such arguments in Finland in 2017. I approach this question through an analysis of efforts by religious media to intervene in the debate on asylum seekers' conversions. More specifically, I examine how journalists writing for the Kirkko ja kaupunki newspaper

2 The manner in which different states solve these questions vary as is reflected by the variety of ways in which secularism is understood and practised across the world. 
grounded their arguments on the need to include religious perspectives on asylum seekers' conversion-based appeals in a register of expertise, and how their arguments for the need for greater state engagement with religious expertise worked to position religious actors in new ways in relationship to Finnish immigration authorities. In developing my analysis, my aims are twofold: Firstly, I seek to describe how Kirkko ja kaupunki journalists positioned religious expertise as an antidote to the challenges that efforts to evaluate conversionbased asylum appeals posed to Finnish Immigration Service employees in this time period. And, secondly, I am motivated by an interest in examining the ways in which confrontations between religious and secular expertise in such matters of governance and adjudication act as a site for negotiations over the 'proper' relationship between religion and state.

My focus on Kirkko ja kaupunki is motivated by the newspaper's status as one of the most important channels of communication between the Evangelical Lutheran Church of Finland and the lay population in a broad sense. According to the Finnish National Media research centre, the paper and online versions of the biweekly newspaper were read on average by 149,000 people in 2018. ${ }^{3}$ Although this does not

3 MediaAuditFinland 2019. This figure reflects a readership of $1.3 \%$ of the total population in the Helsinki region. The newspaper is delivered biweekly to the homes of all members of the Evangelical Lutheran Church in the Helsinki region, approximately $60 \%$ of the households in the region. Kirkko ja kaupunki reported its circulation as 340,000 exemplars in 2018 (Mediakortti 2018). According to Statistics Finland (Tilastokeskus), in the beginning of 2018 there were 572,401 households in total in Helsinki, Espoo, Vantaa and Kauniainen, compare to the ways in which by-subscription non-religious newspapers are read, it nonetheless testifies to Kirkko ja kaupunki's reach within a region in which less than 2 per cent of the members of the Evangelical Lutheran Church attend church services on a weekly basis. ${ }^{4}$ As a result, the newspaper holds a privileged position among the various media produced by Evangelical Lutheran church bodies, officials, and members. It is the media form that is most likely to reach both those church members who attend church services and functions on a regular basis and those whose ties to the church are weak. In consequence, it can be understood to act as a critical site for the construction of the Helsinki region Evangelical Lutheran Church's political and social positions in the national public sphere.

Methodologically, I draw on an analysis of Kirkko ja kaupunki's reportage and commentary on asylum seekers' conversions to Christianity surrounding the socalled 'refugee crisis' in Finland (2015-18). The corpus of data analysed consists of a total of 114 articles, op-eds, comments and opinions that discuss the influx of asylum seekers into Finland and their treatment in the country that were published by Kirkko ja kaupunki between 31 August 2015 and

the region that comprises Kirkko ja kaupunki's distribution zone (Tilastokeskus 2019).

4 Tellingly, a 2015 news report in Kirkko ja kaupunki celebrated the exceptionally high attendance rates of the Helsinki Cathedral parish. In contrast to the regional average of $1.8 \%$ of members attending church services on a weekly basis, this parish attracted an equivalent of $6.5 \%$ of its members to its services on a weekly basis. In practice, however, this number was understood to include large numbers of church members from beyond the parish proper. See Haikala 2015. 
29 June $2018.5^{5}$ The first stage of analysis of the corpus focused on identifying the narrative frames in which the phenomenon of asylum seekers converting to Christianity was discussed in this time period in Kirkko ja kaupunki. A key frame that emerged from this analysis was concern over the limited recognition, on the part of the Finnish Immigration Service (commonly known as Migri), of Evangelical Church officials' religiously grounded expertise on conversion, both on a general level and in the context of efforts to determine the character of the conversion of particular asylum seekers. This frame was particularly prevalent in the newspapers' reporting and commentary on the topic of asylum seekers between November 2016 and January 2018. The second stage of analysis focused on tracing the chronological development of the newspaper's argumentation on the import of recognizing Evangelical Lutheran expertise on conversion in this time period.

\section{Asylum seekers and Evangelical Lutheran congregations}

In 2015-17 Finland, like many other European nations, experienced an unprecedented influx of asylum seekers. At its peak in September and October 2015, the number of asylum seekers entering Finland weekly was in the thousands (see Jauhiainen

5 The corpus consists of all articles published in the newspaper in this time period that could be identified by the researcher as discussing asylum seekers in Finland. The first identified articles on the topic were published on 31.8.2015. See Saaristo 2015; Tiihonen 2015. The final article identified on the topic of asylum seekers in the period under investigation was published on 29.6.2018. See Huttunen 2018. Although the topic did not disappear completely from the pages of the newspaper after this, there was a significant decline in its coverage.
2017: 13). 6 The country's existing structures for receiving asylum seekers were quickly overwhelmed. Among the nongovernmental actors that rushed to the aid of incoming asylum seekers were many of the country's Evangelical Lutheran congregations. Motivated by a Christian ethos of helping those in need (see Siirto and Niemi 2019), they offered their facilities for use as emergency shelters and organized clothing drives. In addition, church members volunteered their time to teach Finnish and provide advice on how to navigate Finnish societal mores and bureaucracies, as well as to organize outings and other activities for asylum seekers. ${ }^{7}$ When the influx of incom-

6 In 2015, a total of 32,476 people applied for asylum in Finland. The majority of these applicants were from Iraq. In 2016, 5637 asylum applications were submitted (including initial applications, reapplications, and transfer applications from elsewhere in the European Union). Most applicants came from Iraq, Afghanistan, Syria, Somalia and Eritrea. In 2017, the number of asylum applications submitted was 5,059 with the majority of applicants coming from Iraq, Syria, Eritrea, Afghanistan, and the Russian Federation (Lyytinen 2019).

7 According to a survey conducted by the Evangelical Lutheran Church, a total of 36 congregations offered their facilities as emergency shelters (Seurakuntakysely 2016). As Hanna Niemi and Ulla Siirto (2017) describe in a study based on interviews conducted with church employees in 2016 , the forms of assistance that different congregations offered to asylum seekers varied widely depending on congregation members' interest in and attitudes towards, as well as experience with, such volunteer work. Many of the congregations that aided asylum seekers in 2015 and 2016 had little to no prior experience with working with immigrant populations. This was especially the case for rural congregations. Almost 50\% of them had not worked with immigrants before 2015. But even in urban settings, where approximately 
ing asylum seekers settled to a number that the Finnish Immigration Service's reception centres could accommodate, the emergency shelters organized by Evangelical Lutheran congregations were closed. But many of the forms of volunteer work that had been begun in autumn 2015 continued. Church members continued to teach Finnish to asylum seekers, organize social events for and with them and provide advice on Finnish society.

By the end of 2016, many members of the church had come to take on increasingly public roles as advocates for asylum seekers. The turn to a more activist stance in engagements with asylum seekers among church officials and members emerged in tandem with, and responded directly to, state efforts to manage and speed up the processing of rapidly growing numbers of asylum applications, to maintain budgetary targets for supporting asylum seekers, and to temper the influx of asylum seekers from other European countries. As the number of asylum seekers entering Finland grew, the Finnish government revised the nation's asylum policies and procedures in several ways. ${ }^{8}$ In 2016 , the laws on asylum were aligned with those of other European Union nations such that humanitarian protection was removed as a criterion for asylum (see Saarikkomäki et al. 2018: 7). In addition, possibilities for family reunification were restricted, asylum seekers' access

$80 \%$ of congregations ran programmes that involved immigrant groups, few had worked with asylum seekers.

8 Already in June 2015, the Finnish Government set the cutting of asylum seekers' uncontrolled flow to the country, the gaining of control of asylum expenses, and the integration of those granted asylum as its short term asylum policy goals (Valtioneuvosto 2015: 1; see Lyytinen 2019: 21; Saarikkomäki et al. 2018: 2). to legal aid was decreased, and the Finnish Immigration Service's asylum processing times were tightened (see Jauhiainen 2017; Lyytinen 2019; Saarikkomäki et al. 2018). Moreover, the Finnish Immigration Service updated its country reports on Afghanistan, Iraq and Somalia, claiming that it was possible for refugees to return to all regions of these countries (see Lyytinen 2019: 20). These changes dramatically decreased the percentage of positive asylum decisions, an outcome that was widely viewed by asylum advocates and analysts as a reflection of serious lapses in due process in the Finnish Immigration Service's asylum proceedings (see ETMU 2017; Horsti 2017; Saarikkomäki et al. 2018). ${ }^{9}$

Evangelical Lutheran criticisms of these developments in asylum policy took many

9 In a comparative analysis of asylum decisions involving young Iraqis in early 2015 and mid-2017, Saarikkomäki et al. (2018) show that the percentage of applicants granted asylum declined dramatically between early 2015 (before the increase in asylum applications) and mid-2017 (when the numbers of asylum applications had returned to rates similar to early 2015). In early $2015,86 \%$ of asylum applicants were granted asylum, whereas in 2017 only $27 \%$ of applications resulted in asylum. As their analysis shows, this decline could not be explained by demographic changes in asylum applicants or by the removal of humanitarian protection from Finnish laws on asylum. Instead, the decline was a clear reflection of a tightening of evaluation criteria for asylum by the Finnish Immigration Service (Saarikkomäki et al. 2018). This analysis is also supported by the high rates at which the Helsinki administrative court overturned the Finnish Immigration Service's asylum decisions in 2016: $24 \%$; $3.6 \%$ of decisions were overturned on the basis of errors made by the Finnish Immigration Service (Maahanmuuttovirasto 2017; see also Jauhiainen 2017: 16, Saarikkomäki et al. 2018: 37). 
forms. On a discursive level, Evangelical Lutheran critiques of the Finnish Immigration Service and its asylum decisions emphasized the decisions' inhumanity and lack of recognition of the dire realities of the countries to which asylum seekers were being deported. In line with other activists, those affiliated with the Evangelical Lutheran church argued that the deported would face almost certain death on return to their countries of origin. ${ }^{10}$ On a practical level, priests, church officials and members joined activist rallies to protest against the Finnish Immigration Service's decisions. ${ }^{11}$ In addition, several churches opened their doors to asylum applicants whose applications had been denied, offering them church sanctuary for the duration of a new appeal process. ${ }^{12}$ However, when it came to asylum seekers who had converted to Christianity, church members also had a different set of concerns.

The question of asylum seekers' potential conversion to Christianity had been a topic of conversation in Evangelical Lutheran congregations well before the Finnish Immigration Service began to receive asylum appeals that claimed such conversion. From their initial engagements with asylum seekers, different congregations had debated the extent to which

10 On civil society and activist critiques of the Finnish state's asylum policies, see ETMU 2017; Horsti 2017).

11 Some Lutheran ministers, most notably Marjaana Toiviainen from Helsinki’s Oulunkylä congregation, who refused police commands to disband a protest at the Helsinki-Vantaa airport in April 2017, even took to civil disobedience to protest the Finnish Immigration Service's deportation decisions.

12 On the history and practice of church sanctuary to aid asylum seekers, see Ahonen 2018. they could appropriately present their religious commitments when working with this highly vulnerable and predominantly Muslim population. While some congregations sought to retain the assistance they provided in a religiously neutral frame, others invited asylum seekers to join church services and other church events. ${ }^{13}$ According to a study conducted in 2016 by Hanna Niemi and Ulla Siirto (2017), many congregations were taken by surprise at the interest that the asylum seekers they assisted expressed in Christianity. Not only did asylum seekers frequently attend church services when invited, but they also appeared keen to learn about Christianity. Many congregations were, however, wary about providing more in-depth religious instruction to asylum seekers before they had been granted asylum (Niemi and Siirto 2017). Still, not all congregations abided by this stance. Over a third of the church officials that responded to Niemi and Siirto's survey surmised that asylum seekers had participated in religious education (Niemi and Siirto 2017: 71). Thus, for example, as an article published in Kirkko ja kaupunki in 2017 reported, the Herttoniemi congregation in Helsinki offered weekly religious education classes in Arabic both in Herttoniemi and over Skype to interested asylum seekers (Jämsä 2017).

Nevertheless, irrespective of individual congregations' or church members' views on the degree to which asylum seekers were to be involved in religious services and religious education before receiving asylum decisions, they found the Finnish

13 Many Evangelical Lutherans also felt that the church should direct its social work to Finns in need instead of asylum seekers. For critical views on asylum seekers among Evangelical Lutherans, see Niemi and Siirto 2017. 
Immigration Service's efforts to assess conversion-based asylum appeals concerning. The Kirkko ja kaupunki newspaper's reporting and commentary on conversion-based asylum appeals not only provides an inside view of the development of Evangelical Lutheran arguments on the matter, but it also constitutes a key channel for developing and broadcasting these arguments.

\section{Religion and faith as beyond state purview}

One of the first interventions in Kirkko ja kaupunki on the Finnish Immigration Service's efforts to evaluate asylum seekers' conversion-based appeals was a column titled 'Asylum interrogation is a modern inquisition' ('Turvapaikkakuulustelu on modernia inkivisitiota'), published on 23 November 2016. The author was Samuli Suonpää, a journalist who is well-known for his polemical writing style. As the title reveals, the column was highly critical of the Finnish Immigration Service's efforts to evaluate asylum seekers' conversion-based appeals. Similar to the inquisitors of fifteenth-century Spain, the column's author Suonpää argued, the Finnish Immigration Service's officials were subjecting asylum seekers to an interrogation on Christian principles. And, similar to the fifteenth century, the stakes of these interrogations were the same; a false answer to such questions as 'explain the Christian concept of the trinity' could result in the penalty of death - whilst in fifteenth-century Spain it would lead to a sentence for heresy, in twenty-first century Finland it could lead to a negative asylum decision, which in practice, could be a death sentence. The only difference was that in present-day Finland the sentencing was being done not by priests, but rather government bureaucrats and judges.

Despite its polemical character, the overall tone of this column aligned well with the ways in which the newspaper and
Evangelical Lutheran congregations had come to position themselves in respect to the wave of asylum seekers that began to arrive into Finland in 2015. For the purposes of my analysis here, what is especially interesting about Suonpääs column is the ways in which he argued that the Finnish Immigration Service was at fault. If the immigration interviews paralleled inquisition interrogations in their form and outcomes, as he claimed, ultimately, an at least as significant a problem with the former, in his analysis, was that they were performed by people who lacked expertise in Christianity. That is, not only were the Finnish Immigration Service's officials subjecting asylum seekers to inquisition-like interrogations, but also they were doing so from a position of ignorance.

As Suonpää explained, the questions that Finnish Immigration Service's officials relied on to evaluate asylum seekers' conversions did not make sense from a Christian perspective. Questions like 'Who is Jesus according to Christianity?' or 'Are you a believer?' ('Oletko uskossa?') did not have straightforward answers, and more importantly did not provide a means to assess the character of their respondents' faith.

This was equally true, Suonpää argued, of the ways in which Finnish Immigration Service officials appeared to understand how being Christian would affect asylum seekers' safety in their countries of origin should they be returned. To exemplify this point, Suonpää drew attention to the suggestion apparently made by some Finnish Immigration Service officials to converted asylum seekers that they refrain from disclosing their faith upon return 'since it wasn't outwardly visible', a suggestion that from a religious point of view was not only preposterous but also directly contradictory to the principle of religious freedom. 
He also drew attention to the constrained ways in which Finnish Immigration Service officials appeared to understand the threat of religious persecution. As the decisions made by these officials revealed, for them religious persecution appeared primarily as a threat from states that criminalized the practice of, or conversion to, other religions than Islam, such as the case of Iran. Persecution by family and neighbours, by contrast, was not perceived as a threat in the same way.

To make matters worse, Suonpää argued, the very questions that the Finnish Immigration Service's officials asked of converted asylum seekers constituted an incursion on the private lives of respondents in ways that extended beyond the state's jurisdiction. As he charged, 'In all healthy societies these kinds of personal and oftentimes painful topics (i.e. those involving faith and the ways in which it would be viewed by one's kin and neighbours) would be considered private and protected.' 14

Ultimately, then, the argument that Suonpääs column mounted against Finnish Immigration Service officials was that they lacked both the expertise and the authority to evaluate asylum seekers' conversions. These were matters, he insisted, that belonged to the purview of the Church and its experts. The task of secular bureaucrats was not to determine the character of an individual's religiosity. Rather, it was to determine if the individual was in danger and if they needed asylum.

Suonpääs column, thus, drew a clear distinction between matters of religious and secular governance and expertise. According to him, matters of faith did not

14 'Kaikissa terveissä yhteiskunnissa juuri nämä henkilökohtaiset ja usein kipeät aiheet kuuluisivat yksityisyyden piiriin ja niitä suojeltaisiin. belong to the field of secular governance. They could only be assessed by religious experts and authorities. This analysis, of course, was premised on the assumption that such a clear distinction between matters of religious and secular expertise and governance could be made. However, as the interviews that Finnish Immigration Service officials conducted with asylum seekers who claimed to have converted to Christianity demonstrated, they did not think the distinction could be sustained in these cases. For them, the threat of persecution could not be evaluated apart from an assessment of the reality of an asylum seekers' conversion.

By January 2017, just two months after Suonpääs column, the arguments that journalists writing for Kirkko and kaupunki were putting forward on what they saw to be the proper relationship between religious and secular officials and expertise had also come to reflect this viewpoint.

\section{The need for religious expertise in secular governance}

On 12 January 2017, Kirkko ja kaupunki reported that the Finnish Ecumenical Council (Suomen Ekumeeninen Neuvosto, SEN) had published a highly critical report on the status of religious rights in Finland (Huttunen 2017). ${ }^{15}$ The council, an organ composed by Finland's various Christian churches and organizations, had been commissioned by the Finnish Ministry for Foreign Affairs to produce the report as part of Finland's contribution to the United Nations Human Rights Commission's Universal Periodic Review on the status of

15 The report that the article referred to is 'Suomen ekumeenisen neuvoston lausunto YK:n ihmisoikeusneuvoston yleismaailmalliseen määräaikaistarkasteluun (UPR)', 2017. 
human rights in the country. The report, the article in Kirkko ja kaupunki emphasized, drew attention to severe problems in the Finnish Immigration Service's treatment of asylum appeals based on claims to religious conversion. According to the council, the Finnish Immigration Service's treatment of such cases revealed a significant lack of knowledge about the character of religious belief and practice in different religious traditions, religious freedom, and religious persecution. As a result, the Finnish Immigration Service's decisionmaking process infringed on asylum seekers' rights in various ways.

As a remedy to this situation, the council recommended that Finnish immigration officials be provided with training in matters related to religion in three areas. First, their knowledge of the variety of different Christian congregations in Finland and the various ways in which faith and conversion were understood in them needed to be expanded. According to the council's report, it was integral that immigration officials understood and recognized that there were significant differences in the kind of religious knowledge that was required when joining congregations and that for example the ways in which religious ceremonies were represented and celebrated could vary quite dramatically across, as well as also within, religious traditions. In addition, the report called attention to the need to understand that the ways in which Christian principles were conceptualized and interpreted varied greatly between different traditions. Second, the report argued that Immigration Service officials needed to be better educated on the principle of religious freedom, and the ways in which it always needed to be taken into account in their treatment of and decisions on asylum applications. As the report stated, the right to freedom of religion was absolute. It could not be infringed upon in any circumstances. Third, the council called on government officials to develop their expertise in, and more sensitive mechanisms for identifying, religious persecution. As the report stated, the burden of proof of the threat of religious persecution could not be laid on asylum seekers, as it was oftentimes impossible for them to provide sufficient evidence of it or to describe it coherently to immigration officials. It was also integral that immigration officials recognize and account for the fact that the forms of religious persecution asylum seekers typically faced were not limited to state-sanctioned or legally prescribed persecution, but could also involve persecution by the asylum seeker's own kin group.

The Finnish Immigration Service took the report and the conversations they had had with the Finnish Ecumenical Council prior to the report's publication seriously. On 19 January 2017, a week after the publication of the Finnish Ecumenical Council's report, Kirkko ja kaupunki reported: 'The Finnish Immigration Service wishes for help from the churches and Seta' ('Maahanmuuttovirasto toivoo kirkoilta ja Setalta apua') (Juusela 2017a). The article quoted Hanna Helinko, Director of the Legal and Country Information Unit of the Finnish Immigration Service saying: 'The quality of our asylum decisions is important to us. That is why we want to expand our expertise in processing the asylum applications of those who have converted to Christianity. The Finnish Ecumenical Council will come and train the personnel of the asylum unit in January. Training will be provided in conversion from one religion to another and baptism in different Christian traditions.' 16

16 'Meille on tärkeää turvapaikkapäätöstemme laatu. Siksi haluamme lisätä 
Drawing a parallel to the ways in which Seta (the main national-level organization for LGBTI rights in Finland) had trained the Finnish Immigration Service's employees on the diversity of sexual orientation and gender expression since 2012, the report enthusiastically presented the Immigration Service's interest in collaborating with the Finnish Ecumenical Council as the beginning of a new kind of collaborative relationship between religious communities and state immigration officials. This enthusiasm for what appeared to be a new kind of openness towards religious expertise was also communicated through the Kirkko ja kaupunki report's description of the Finnish Ecumenical Council's analysis of the changes. According to the report Mari Pöntinen, Head Secretary of the Finnish Ecumenical Council considered the situation to already be somewhat better than what it had been when the research for the statement had been conducted. Since then, officials of the Finnish Immigration Service had met with representatives of the Ecumenical Council twice. Moreover, Pöntinen suggested, the problems that the council had observed, needed to be viewed with respect to the fact that the period under analysis had coincided with a highpoint in immigration when the Immigration Service had been operating under great pressure, and as a result of having to hire new personnel in a hurry. As the Finnish Immigration Service's officials themselves seemed to be recognizing, their processing of asylum seekers' conversionbased appeals had suffered from a lack of

asiantuntemustamme kristinuskoon kääntyneiden turvapaikkahakemusten käsittelyssä. Suomen ekumeeninen neuvosto tulee tammikuussa kouluttamaan turvapaikkayksikön henkilöstöä. Koulutusta annetaa uskonnosta toiseen kääntymisestä ja kasteesta eri kristillisissä perinteissä.' expertise on religion. But, now that this had been pointed out to them, they were invested in remedying the situation with the help of experts from inside the religious communities concerned. ${ }^{17}$

Such analyses of the Finnish Immigration Service's increased openness to religious expertise gained even further support on the basis of two other actions that the Immigration Service took in the beginning of 2017. Firstly, the Immigration Service created a new post within its offices for a religion specialist that was filled by Anu Karppi, a Finnish Immigration Service employee who held a Master's degree in Theology. Moreover, the Finnish Immigration Service decided to give more weight to statements written by church officials on asylum seekers' conversions and participation in their congregations. Until then, such statements had tended to be treated as biased and subjective views instead of actionable objective reports. This had especially been the case for statements from pastors of smaller Pentecostal congregations that were not well-known to Finnish Immigration Service officials.

However, as soon became clear, if the Finnish Immigration Service appeared to be open to redrawing the lines between religious expertise and secular governance when it came to asylum seekers'

17 Enthusiasm for this new configuration of religious and secular expertise and governance was also shared by other religious media publications. Thus, for example Ristin Voitto, a media publication of the Finnish Pentecostal movement, praised the new ways in which the Finnish Immigration Service had committed to collaborating with and consulting religious leaders in a long article published on 12 January 2017 that was titled 'Migri and churches are searching for a common note' ('Migri ja kirkot etsivät yhteistä säveltä) (Salmela 2017). 
conversion-based appeals, the ways in which they envisioned their new engagements with religious experts and expertise differed quite drastically from Church representatives' understandings of the Finnish Ecumenical Council's recommendations.

\section{Subjective versus objective knowledge}

On 31 March 2017, Kirkko ja kaupunki reported: 'According to the director of Migri [the Finnish Immigration Service], special experts on religious studies are not needed in assessing asylum applications' ('Migrin johtaja: Turvapaikkahakemuksen arvioimisessa ei tarvita uskontotieteen spesiaaliosaajaa') (Kylätasku and Haikala 2017). The article was based on an interview with Esko Repo, Director of the Asylum Unit of the Finnish Immigration Service, on a decision to deny asylum to a Christian family from Pakistan. The father of the family was a Christian pastor who had received death threats from Islamists in Pakistan, including a statement from an imam that declared killing him would be considered an act of rightful jihad. To save himself and his family, the man and his family had fled Pakistan. Upon arrival in Finland, the family had applied for asylum. The family's asylum application was, however, denied by the Finnish Immigration Service. In the Immigration Service's view, the family's fears of persecution were not objectively justified. Christians were not generally persecuted in Pakistan.

The decision was strongly criticized by the Kirkko ja kaupunki newspaper. Contesting the Finnish Immigration Service's analysis of the prevalence of religious persecution against Christians in Pakistan. the newspaper pointed to Pakistan's high position on the Christian organization Open Doors' 'World Watch List' on Christian persecution. This list considered Pakistan to be the world's fourth most dangerous country for Christians at the time. When questioned on the decision by Kirkko ja kaupunki, Repo contested the need to consult such reports arguing that the service's own expertise on religious persecution was sufficient. The unit on religious persecution at the Finnish Immigration Service, he claimed, employed a special expert on the matter. Who this special expert was, or what their expertise consisted of, was not mentioned, but Repo made clear that in this context the Finnish Immigration Service viewed reports on Christian persecution produced by non-governmental religious organizations like Open Doors with skepticism. Drawing a sharp distinction between subjective and objective knowledge, he argued that as a government agency, the Immigration Service had to ground its decisions on objective knowledge, a category which in this case at least excluded reports by organizations like Open Doors.

Over the following months, the limits of Finnish Immigration Service officials' openness to religious expertise was further revealed as lists of questions that Finnish Immigration Service employees were asking converted asylum seekers in asylum interviews began to circulate in the Finnish public sphere. Although the Finnish Immigration Service officials claimed that the questions were designed to assess the meaning that Christianity, and conversion to it, had for the asylum seeker in question and the ways in which it influenced their everyday lives, the lists that were circulated suggested that in fact many of the interviews were more focused on assessing the interviewees' knowledge of Christianity and Christian principles. Such a focus on knowledge directly contravened religious understandings of Christian faith and in so doing suggested that despite the Finnish Ecumenical Council recommendations, religious views on the character of faith and 
conversions had not been taken into account in the devising of interview questions by Finnish Immigration Service officials.

In response to the publicly circulating question lists, over 400 Christian ministers signed a petition that called on immigration officials to better take into account religious representatives' expertise in the assessment of conversion-based asylum applications. The petition was delivered to Finland's Ministry of the Interior in September 2017. In Kirkko ja kaupunkis report on the petition, Kaisa Huhtala, the vicar of the Teljä congregation in Pori, and the first signatory of the petition, argued that the petitions signatories recognized that immigration officials needed to assess the sincerity of faith in these asylum cases, but they wished the Finnish Immigration Service would listen better to religious experts in their efforts to do so (Juusela 2017 b). Many of the questions on the publicly circulated lists were such that the majority of congregation members would have been unable to answer them. In addition, it was clear that many of the hearings had suffered from problems related to interpreters who were not adequately prepared or trained to translate asylum seekers' responses on Christianity. The solution to these problems that Huhtala and her co-signatories proposed was for Finnish Immigration Service officials to enter into a more substantive dialogue with religious actors both in their efforts to develop better interview questions, and in their overall assessments of individual cases. As Huhtala emphasized in her responses to Kirkko ja kaupunki, typically the conversion and baptism of asylum seekers was the result of a long process. The ministers who baptized these individuals accompanied much of this process. As a result, they had a much deeper and longer-standing understanding of the character of an individual asylum seeker's faith than the immigration officials who interviewed him or her.

The delivering of the petition was followed by a series of articles in Kirkko ja kaupunki that argued that Christian faith was not based on, or assessable by, knowledge. One of these articles drew on an interview with Risto Saarinen, Professor of Ecumenical Studies and Director of the Reason and Religious Acceptance Centre of Excellence at the University of Helsinki. In what could be understood as an effort by the publication to expand the constrained frame of religious expertise that the Finnish Immigration Service appeared to be operating under, the article quoted Saarinen, an academic expert on Christianity, arguing that Christian faith was not a structure of knowledge but rather one of trust. ${ }^{18}$ Another set of articles drew attention to reports on one asylum seeker having been asked by Finnish Immigration Service officials to describe the different ways in which the Gospels of Matthew and

18 'In Christianity, faith is first and foremost described as trust in God in Jesus Christ. Faith is not any kind of theoretical thing that requires the listing of knowledge contents, but instead a structure of trust.' ('Kristinuskossa uskoa kuvataan ennen kaikkea luottamuksena Jumalaan Jeesuksessa Kristuksessa. Usko ei ole mikään teoreettinen juttu, jossa pitäisi luetella jotain oppisisältöjä, vaan luottamusrakenne.') He continued: 'In the Lutheran church small children and those with less mental and intellectual ability have been considered believers in just the same way as the learned. Faith is not a knowledge-based capacity, but a simple thing for which no special explanations are needed.' ('Luterilaisessa kirkossa on ajateltu, että pienet lapset ja henkisiltä kyvyiltään ei niin älykkäät ihmiset voivat olla ihan samalla tavalla uskovaisia kuin oppineet. Usko ei ole tiedollinen kyky, vaan yksinkertainen asia, johon ei vaadita ihmeellisiä selityksiä.') 
Mark described Jesus' instituting of communion, a question that, as the newspaper observed, would have not been easy to answer even for people trained as ministers in the Lutheran Church.

If the Finnish Ecumenical Council's report in January 2017 contributed to changes in the Finnish Immigration Service's engagements with religious experts and expertise, this petition and the discussion it raised had quite a different effect. Rather than shift the terms of engagement between religious and secular state actors, they pushed Immigration Service officials to draw a sharper and more explicit line between their own expertise and that of religious authorities. This was clear in the ways in which Anu Karppi, the Finnish Immigration Service's asylum unit's religion expert responded to Kirkko ja kaupunkis queries on the use of knowledgebased questions in Immigration Service interviews in November 2017 (Juusela 2017c). In her response, Karppi emphasized that such questions were not the main objective of the interviews. Rather, the aim of the interviews was to assess the asylum seekers' motives for leaving their previous religion and the stability and permanence of their commitment to the new religion. Thus, over all, knowledge-based questions, were not of central importance to the interviews. But, they could play a role in assessing how well asylum seekers had familiarized themselves with their new religion. As Karppi emphasized, the interviews frequently took more than a day and involved a large number of questions, at times even more than one hundred. In this context, the assessment that was made was based on a comprehensive evaluation of all that was known about the applicant and not just an individual question. Ultimately, then, she did not consider the religious criticism of the Finnish Immigration Service's interviews valid. Instead, she emphasized that she had full confidence in the expertise of the Immigration Service's senior advisors (ylitarkastaja) and was convinced that they must have had a good reason for asking this particular question. As she suggested, religious authorities should too. After all, the Finnish Immigration Service had had its personnel trained by the Finnish Ecumenical Council.

As Karppi's responses suggested, the potential of the religious expertise argument to shift the terms of engagement between religious actors and immigration officials in respect to asylum seekers' conversion-based appeals had not only reached a limit but also Finnish Immigration Service officials had begun to push back against religious actors' criticisms of their lack of expertise. If the frame of expertise had provided religious actors with a means to momentarily reposition the line between religion and state, the frame was now being engaged by the Finnish Immigration Service's officials for the same purpose.

\section{Conclusion}

As Timothy Mitchell (2002) has described, questions of governance have become the purview of different kinds of experts (bureaucrats, technocrats, advisors, etc.). This is also true for the processing of asylum applications. In its efforts to assess asylum applications the Finnish Immigration Service draws on a broad range of experts: experts in its own country and religion, who produce reports on the political and social situation of asylum seekers' countries of origin and the range of ways in which different religions are practised and experienced; reports on other countries produced by experts employed by other organizations; guidelines produced by experts working for the UNHCR and EU on how to assess asylum applications - and 
so on. Such reliance on experts, as Esko Repo's emphasis on 'objective knowledge' highlights, is designed to ensure that the Finnish Immigration Service's asylum decisions are objectively grounded, rationally motivated, and, ultimately, politically neutral and fair.

From this perspective, it is not surprising that the Kirkko ja kaupunki newspaper and the Evangelical Lutheran church officials it quoted would choose to emphasize the need to recognize the expertise of church officials and Christian research institutes in assessing conversion-based asylum appeals. As I have recounted in this article, such arguments provided these commentators with opportunities to establish a new kind of foundation for their conversations with, and critical analyses of, the Finnish Immigration Service. In emphasizing the expert character of church officials' and Christian research institutes' knowledge of the character of faith and religious persecution, they effectively positioned these officials and research institutes on a similar footing with the other experts that the Immigration Service has relied on to assess asylum applications and appeals.

The Finnish Immigration Service's reticence to engage their arguments for the greater recognition of religious expertise in the assessment of conversion-based asylum applications, however, reveal the limitations of this endeavour. As it shows, what, ultimately, counts as objective knowledge in a given state context is not only determined by its adherence to criteria of objectivity but also by the particular ways in which the experts that produce it and the institutions they represent are and have been positioned in relationship to the state. The relationship of religious expertise to matters of secular governance constitutes a case in point as it brings the tense and ever irresolvable relationships between religion and the state in secular polities that form the core of the problem-space of secularism into focus. As Evangelical Lutheran church officials' and members' calls for religious experts and their expertise to be included in the assessment of asylum applications based on religious arguments and the Finnish Immigration Service's efforts to compartmentalise religious expertise off from the categories of objective knowledge reveal, where the line between Evangelical Lutheran Christianity and the Finnish state should be drawn is by no means clear. Rather, the intersection between the two and its location retain the status of being objects of constant and ultimately neverending contestation.

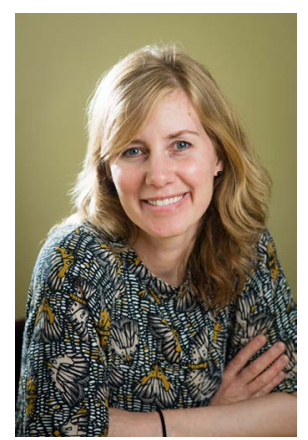

Elina I. Hartikainen is an Academy of Finland Academy Research Fellow based in Social and Cultural Anthropology at the University of Helsinki. Her research examines religious engagements with state structures in the context of legal processes, democracy promotion projects, and multicultural policy. Most recently, her research has been published in American Anthropologist, American Ethnologist, and Signs and Society. Currently, she is finishing a book manuscript on the politicization of practitioners of the Afro-Brazilian religion, Candomblé, in early 2000s Brazil, and beginning research for an ethnographic study of secularism and the prosecution of religious intolerance against AfroBrazilian religions in Brazil.

\section{References}

Media sources

Haikala, Topias, 2015. 'Jumalanpalveluksissa käyminen on yleistynyt', Kirkko ja kaupunki, 11.6.2015, <https://www.kirkkojakaupunki. fi/-/jumalanpalveluksissa-kayminen-onyleistyn-1> (accessed 24.6.2019)

Huhtanen, Ann-Mari, 2018. 'Villeissä pienseurakunnissa tapahtuu kummia, kun turva- 
paikanhakijat kääntyvät joukoittain kristinuskoon. HS selvitti, kenen aloitteesta kasteita annetaan ja millaisia motiiveja kääntyneillä on', Helsingin Sanomat, 4.3.2018, <https://www.hs.fi/kotimaa/art2000005590370.html $>$ (accessed 16.4.2019)

Huttunen, Juhani, 2017. 'Kirkot: Viranomaiset eivät ymmärrä uskonnollista vainoa', Kirkko ja kaupunki, 12.1.2017, <https://www.kirkkojakaupunki.fi/-/kirkot-viranomaiseteivat-ymmarra-uskonnollista-vain-1> (accessed 16.4.2019)

- -2018. 'Syyriaan sotaan pakotettu Ismail pelkkää karkotusta: "Iran tappaa minut".' Kirkko ja kaupunki, 29.6.2018, <https:// www.kirkkojakaupunki.fi/-/syyriaansotaan-pakotettu-afgaani-pelkaa-karkotusta-iran-tappaa-minut-> (accessed 24.6. 2019)

Jämsä, Esko, 2017. 'Irakilainen turvapaikanhakija Elijah löysi Suomessa Jumalan, joka rakastaa, Kirkko ja kaupunki, 17.7.2017, $<$ https://www.kirkkojakaupunki.fi/-/elijah-kaantyi-kristityksi-vieraassa-maassa> (accessed 29.6.2019)

Juusela, Pauli, 2017a. 'Maahanmuuttovirasto toivoo kirkoilta ja Setalta apua', Kirkko ja kaupunki, 19.1.2017, <https://www.kirkkojakaupunki.fi/-/maahanmuuttovirastotoivoo-kirkoilta-ja-setalta-apua> (accessed 16.4.2019)

- - 2017b. 'Yli 400 pappia vetoaa sisäministeriöön kristityiksi kääntyneiden turvallisuuden puolesta, Kirkko ja kaupunki, 6.9.2017, <https://www.kirkkojakaupunki. fi/-/yli-40o-pappia-vetoaa-sisaministerioon-kristityiksi-kaantyneiden-turvallisuuden-puolesta> (accessed 16.4.2019)

——2017c. 'Migri: Kristinuskoon kääntyneiden turvapaikkapuhuttelu voi sisältää yli 100 kysymystä, Kirkko ja kaupunki, 2.11.2017, <https://www.kirkkojakaupunki.fi/-/migrikristinuskoon-kaantyneiden-turvapaikkapuhuttelu-voi-sisaltaa-yli-100-kysymysta> (accessed 16.4.2019)

Kylätasku, Taneli, and Topias Haikala, 2017. 'Migrin johtaja: Turvapaikkahakemuksen arvioimisessa ei tarvita uskontotieteen spesiaaliosaajaa, Kirkko ja kaupunki, 31.3.2017, <https://www.kirkkojakaupunki.fi/-/ esko-repo-turvapaikanhakijan-kertomuksen-arvioimisessa-ei-tarvita-uskontotieteen-spesiaaliosaajaa> (accessed 16.4.2019)

Saaristo, Sari, 2015. 'Kirkon Ulkomaanapu aloittaa Eurooppaan saapuneiden pakolaisten auttamisen', Kirkko ja kaupunki, 31.8.2015, <https://www.kirkkojakaupunki.fi/-/ kirkon-ulkomaanapu-aloittaa-eurooppaansaapuneiden-pakolaisten-auttamis-1> (accessed 24.6.2019)

Salmela, Heikki, 2017. 'Migri ja kirkot etsivät yhteistä säveltä, Ristin Voitto, 12.1.2017, $<$ https://www.ristinvoitto.fi/ristin_voitto/ uutiset/migri_ja_kirkot_etsivat_yhteista_ savelta/> (accessed 16.4.2019)

Suonpää, Samuli, 2016. 'Turvapaikkakuulustelu on modernia inkvisitiota', Kirkko ja kaupunki, 23.11.2016, <https://www.kirkkojakaupunki.fi/-/suonpaa-turvapaikkakuulustelu-on-modernia-inkvisitio-1> (accessed 16.4.2019)

Tiihonen, Pihla, 2015. 'Kirkko kerää miestenvaatteita pakolaisille', Kirkko ja kaupunki, 31.8.2015, <https://www.kirkkojakaupunki.fi/-/kirkko-keraa-miestenvaatteitapakolaisil-1> (accessed 24.6.2019)

\section{Bibliography}

Agrama, Hussein Ali, 2010. 'Secularism, sovereignty, indeterminacy: is Egypt a secular or a religious state?' Comparative Studies in Society and History, 52(3), pp. 1-29, <https:// doi.org/10.1017/s0010417510000289>

Ahonen, Talvikki. 2018. 'Kirkkoturvainstituution muotoutuminen Suomessa', Uskonnontutkija - Religionsforskaren 7(1), <https:// doi.org/10.24291/uskonnontutkija. v7i1.71204>

Asad, Talal, 2003. Formations of the Secular: Christianity, Islam, Modernity (Stanford University Press)

Bowen, John R., 2007. Why the French Don't Like Headscarves: Islam, the State, and Public Space (Princeton University Press)

ETMU, 2017. 'Etnisten suhteiden ja kansainvälisen muuttoliikkeen tutkimuksen seuran (ETMU ry) kannanotto Suomen turvapaikkapolitiikkaan', ETMU ry., 15.3.2017, $<$ https://etmu.fi/blogi/etmu-ryn-kannanotto-suomen-turvapaikkapolitiikkaanetmus-statement-finnish-asylum-policy/> (accessed 28.6.2019)

Fernando, Mayanthi L., 2014. The Republic Unsettled: Muslim French and the Contradictions of Secularism (Durham NC, Duke University Press), <https://doi. org/10.1215/9780822376286>

Horsti, Karina, 2017. 'Unjust to everyone? Responses to deportation of asylum seekers in Finland', Open Democracy, 19.5.2017, 
$<$ https://www.opendemocracy.net/en/caneurope-make-it/injustice-to-everyone-moral-responses-to-deportation-of-asylum-seekers-in-finland/> (accessed 28.6. 2019)

Jauhiainen, Jussi, 2017. 'Johdanto ja johtopäätökset', Turvapaikka Suomesta? Vuoden 2015 turvapaikanhakijat ja turvapaikkaprosessit Suomessa, ed. Jussi Jauhiainen, Turun yliopiston maantieteen ja geologian laitoksen julkaisuja, 5 (Turku, Turun yliopisto), pp. 5-18, <http://urmi.fi/wpcontent/uploads/2017/04/URMI-1.pdf> (accessed 28.6.2019)

Lyytinen, Eveliina, 2019. 'Johdanto', Turvapaikanhaku ja pakolaisuus Suomessa, ed. Eveliina Lyytinen (Turku, Siirtolaisuusinstituutti), pp. 15-38, <http://www.migrationinstitute.fi/files/pdf/tutkimuksiasarja/t-02-isbn_978-952-7167-60-1-turvapaikanhaku_ja_pakolaisuus_suomessa. pdf $>$ (accessed 28.6.2019)

Maahanmuuttovirasto, 2017. 'Maatietoraportit päivitetty. Maahanmuuttovirasto tarkentanut päätöskäytäntöään pitkin syksyä, 17.1.2017, < <ttps://migri.fi/artikkeli/-/ asset_publisher/maatietoraportit-paivitetty-maahanmuuttovirasto-tarkentunut-paatoskaytantoaan-pitkin-syksya> (accessed 28.6.2019)

MediaAuditFinland, 2019. 'KMT 2018 lukijamäärät ja kokonaistavoittavuudet', MediaAuditFinland, <http://mediaauditfinland.fi/wp-content/uploads/2019/06/ KMT-2018-lukijamäärät.pdf> (accessed 29.6.2019)

Mediakortti, 2018. Kirkko ja kaupunki, press packet, <https://www.google.com/url?sa=t \&rct $=\mathrm{j} \& \mathrm{q}=\& \mathrm{esrc}=\mathrm{s} \&$ source $=\mathrm{web} \& \mathrm{~cd}=1 \& \mathrm{v}$ ed=2ahUKEwil_7qMspHjAhXiyKYKHUZ xC1 UQFjAAegQIAxAC\&url=https\%3 A\%2 F\%2Fwww.kirkkojakaupunki.fi\%2Fdocum ents\%2F 20147\%2F1469428\%2FMediakortt i\%2BKjak2018_v3.pdf\%2F832676ca-c9331b7a-35c3-f6a6oa9436b7\%3Fdownload\%3 Dtrue\&usg=AOvVaw17ktrXDj9djUM2AF 9sn9V4> (accessed 30.6.2019)

Mitchell, Timothy, 2002. Rule of Experts: Egypt, Techno-Politics, Modernity (Berkeley, University of California Press)

Niemi, Hanna, and Ulla Siirto, 2017. Hätämajoituksesta Aleppon kelloihin. Evankelisluterilaisten seurakuntien turvapaikkatyö Suomessa, Kirkon tutkimuskeskuksen julkaisuja, 49 (Tampere, Kirkon tutkimuskeskus)

Saarikkomäki, Elsa et al., 2018. Kansainvälistä suojelua koskevat päätökset Maahanmuuttovirastossa 2015-2017. Pilottitutkimus 18-34-vuotiaita Irakin kansalaisia koskevista myönteisistä ja kielteisistä päätöksistä, Turun yliopiston oikeustieteellisen tiedekunnan tutkimusraportteja ja katsauksia 1/2018 (Turku, Turun yliopisto)

Seurakuntakysely, 2016. Kysely seurakunnille ja seurakuntayhtymille koskien toimintaa nelivuotiskaudella 2012-2015 (Tampere, Kirkon tutkimuskeskus)

Siirto, Ulla, and Hanna Niemi, 2019. 'Solidaarista yhdessä elämisen taitoa vai vieraanvaraisuutta: evankelisluterilaiset seurakunnat turvapaikkatyössä, Turvapaikanhaku ja pakolaisuus Suomessa, ed. Eveliina Lyytinen (Turku, Siirtolaisuusinstituutti), pp. 231-52, <http://www.migrationinstitute.fi/ files/pdf/tutkimuksia-sarja/t-02-isbn_978952-7167-60-1-turvapaikanhaku_ja_ pakolaisuus_suomessa.pdf> (accessed 28.6.2019)

Sullivan, Winnifred Fallers, 2005. The Impossibility of Religious Freedom (Princeton University Press)

'Suomen ekumeenisen neuvoston lausunto YK:n ihmisoikeusneuvoston yleismaailmalliseen määräaikaistarkasteluun (UPR)', Suomen ekumeeninen neuvosto, 11.1.2017, $<$ http://www.ekumenia.fi/etusivu/ajankohtaista___aktuellt/suomen_ekumeenisen_ neuvoston_lausuntoykn_ihmisoikeusneuvoston_yleismaailmalliseen_maaraaikaistarkasteluun_upr_1112017/> (accessed 16.4.2019)

Tilastokeskus, 2019. 'Kuntien avainluvut', Tilastokeskus (Statistics Finland), <http:// www.stat.fi/tup/alue/kuntienavainluvut. html\#? year=2019\&active $1=$ SSS $>$ (accessed 24.6.2019)

Valtioneuvosto 2015. Hallituksen turvapaikkapolittinen toimenpideohjelma (Helsinki, Valtioneuvosto), <https://valtioneuvosto.fi/documents/10184/1058456/ Hallituksen+turvapaikkapoliittinen+toi menpideohjelma+8.12.2015/98990892co8e-4891-8c23-od229f1d6099> (accessed 28.6.2019) 